\title{
Pembinaan sistem manajemen usaha keramba jaring apung melalui percontohan usaha
}

\author{
Irwan Effendi*, \& Sri Wahyuni
}

Fakultas Perikanan dan Ilmu Kelautan, Universitas Riau

* helpingirwan@gmail.com

\begin{abstract}
Abstrak. Keramba jaring apung (KJA) merupakan salah satu budidaya intensif yang banyak dilakukan di tanah air dan jumlahnya semakin meningkat, termasuk di Danau PLTA Koto Panjang, Kampar. Di daerah ini usaha ini sudah dimulai sejak tahun 1995 dan terus berkembang pesat dan mencapai puncaknya pada tahun 2010-2012. Tahun-tahun berikutnya bisnis ini mulai relatif stagnan dan keuntungan yang diperoleh para pengusaha terus menurun. Akibatnya banyak pengusaha yang mengalami kebangkrutan dan menutup usaha. Berlatarbelakang ini penulis tertarik untuk membuat unit usaha percontohan sebagai role model pola manajemen usaha yang tepat bagi usaha KJA. Kegiatan pengabdian masyarakat ini bertujuan untuk membantu para pengusaha keramba ikan dalam manajemen usaha melaui pemberian contoh langsung usaha yang serupa. Metoda penyuluhan dan pembinaan yang digunakan adalah demonstrasi melalui percontohan langsung dan komunikasi informal dengan para pengusaha binaan. Role model ini mulai dibangun sejak tahun 2010, dimulai dari 6 unit keramba, usahanya tumbuh dan pada saat ini sudah berjumlah 60 unit keramba. Namun kegiatan pembinaan lebih intensif dilaksanakan sejak tahun 2012. Sebanyak 5 pengusaha dijadikan target binaan utama. Hasilnya 5 pengusaha ini beberapa pengusaha lainnya mulai meniru pola manajemen usaha yang diterapkan di role model dan mereka sampai saat ini masih dapat bertahan dan mulai langkah baru pengembangan usaha tersebut.
\end{abstract}

Kata kunci: pembinaan usaha keramba; keramba jaring apung; PLTA koto panjang; manajemen usaha; keramba percontohan; role model

\begin{abstract}
Floating cage (KJA) is one of the most intensive aquaculture activities carried out in the country and the number is increasing, including in the Koto Panjang Hydroelectric Lake, Kampar. In this area this business has been started since 1995 and continues to grow rapidly and reaches its peak in 2010-2012. In the following years the business began to be relatively stagnant and profits from entrepreneurs continued to decline. As a result, many entrepreneurs went bankrupt and closed businesses. With this background, the writer is interested in making a pilot business unit as a role model for the right business management pattern for KJA businesses. This community service activity aims to help fish cage entrepreneurs in business management through direct examples of similar businesses. The counseling and coaching methods used are demonstrations through direct pilot and informal communication with fostered entrepreneurs. This role model began to be built since 2010, starting from 6 cage units, the business is growing and currently there are 60 cage units. However, more intensive coaching activities have been carried out since 2012. A total of 5 entrepreneurs were targeted as the main target. As a result of these 5 entrepreneurs, several other entrepreneurs have begun to imitate the business management patterns applied in the role model and they are still able to survive and start a new step in developing the business.
\end{abstract}

To cite this article: Effendi, I., \& S. Wahyuni. 2019. Pembinaan sistem manajemen usaha keramba jaring apung melalui percontohan usaha. Unri Conference Series: Community Engagement 1: 634-638

https://doi.org/10.31258/unricsce.1.634-638

(C) 2019 Authors

Peer-review under responsibility of the organizing committee of Seminar Nasional Pemberdayaan Masyarakat 2019 


\section{PENDAHULUAN}

Keramba jaring apung (KJA) merupakan salah satu budidaya intensif yang banyak dilakukan di tanah air dan jumlahnya semakin meningkat, termasuk di Danau PLTA Koto Panjang, Kampar. Di daerah ini usaha KJA sudah dimulai sejak tahun 1995 dan terus berkembang pesat dan mencapai puncaknya pada tahun 2010-2012. Pada beberapa tahun belakangan ini usaha ini menemui beberapa kendala. Degradasi lingkungan yang berakibat degradasi kualitas air, hampir tak terelakkan. Fluktuasi suhu ekstrim, penurunan kadar oksigen terlarut, meningkatnya keasaman perairan telah berdampak negatif pada pertumbuhan ikan. Di satu sisi harga pakan dan benih ikan semakin meningkat, di sisi lain daya beli masyarakat melemah dan harga ikan tidak mengalami kenaikan yang signifikan. Pertumbuhan ekonomi di tanah air yang lambat telah pula berdampak terhadap daya beli masyarakat terhadap ikan. Akibatnya beberapa tahun belakangan ini bisnis KJA mulai relatif stagnan dan keuntungan yang diperoleh para pengusaha terus menurun. Dampaknya banyak usaha pengusaha yang mengalami kebangkrutan dan menutup usaha mereka.

Penomena unik lain bagi para pengusaha KJA adalah relatif susah ditemui. Mereka sudah terbiasa hidup berkecukupan dari hasil kerambanya dan merasa tidak membutuhkan bantuan orang lain. Mereka cenderung merasa sangat tahu dengan segala teknis budidaya ikan di dalam keramba dan lika-liku bisnis usaha ini. Akibatnya mereka merasa tak perlu pula dibina dan dibimbing. Berlatarbelakang ini penulis tertarik untuk membina mereka melalui sebuah unit usaha percontohan sebagai yang diharapkan dapat "role model" pola manajemen usaha bagi usaha KJA, khususnya di lingkungan Waduk PLTA Koto Panjang, Kampar, Riau.

\section{Perumusan masalah}

KJA merupakan salah satu budidaya intensif yang banyak dilakukan di Danau PLTA Koto Panjang, Kampar. Riau. Pada beberapa tahun belakangan ini usaha ini menemui beberapa kendala (Dinas Perikanan Kabupaten Kampar, 2016). Degradasi lingkungan yang berakibat degradasi kualitas air hampir tak terelakkan. Fluktuasi suhu ekstrim, penurunan kadar oksigen terlarut, meningkatnya keasaman perairan telah berdampak negatif pada pertumbuhan ikan. Harga pakan dan benih ikan semakin meningkat, namun di sisi lain daya beli masyarakat melemah dan harga ikan tidak mengalami kenaikan yang signifikan. Pertumbuhan ekonomi di tanah air yang lambat telah pula berdampak terhadap daya beli masyarakat terhadap ikan. Akibatnya beberapa tahun belakangan ini bisnis KJA mulai relatif stagnan dan keuntungan yang diperoleh para pengusaha terus menurun. Dampaknya banyak usaha pengusaha yang mengalami kebangkrutan dan menutup usaha. Penomena unik lain bagi para pengusaha KJA adalah relatif susah ditemui. Mereka sudah terbiasa hidup berkecukupan dari hasil kerambanya dan tidak membutuhkan bantuan orang lain. Mereka cenderung merasa sangat tahu dengan segala teknis budidaya ikan di dalam keramba dan lika-liku bisnis usaha ini. Akibatnya mereka merasa tak perlu pula dibimbing. Untuk para pengusaha ini perlu dibina dan dibimbing dengan cara khusus, yaitu unit usaha percontohan "role model" pola manajemen usaha bagi usaha KJA, khususnya di daerah ini.

\section{Tujuan kegiatan pengabdian}

Kegiatan pengabdian kepada masyarakat ini bertujuan untuk membina sistem manajemen usaha para pengusaha keramba di Waduk PLTA Koto Panjang, Kampar,Riau.

\section{METODE}

\section{Lokasi dan waktu pengabdian}

Kegiatan pengabdian ini dilaksanakan di Waduk PLTA Koto Panjang, Desa Pulau Gadang, Kecamatan XIII Koto Kampar, Kabupaten Kampar, Provinsi Riau. Adapun waktunya dilaksanakan bulan 2012-2019.

\section{Pembangunan unit usaha role model}

Kegiatan penyuluhan pola pembinaan budidaya ikan di dalam keramba diawali dari pebangun unit usah keramba milik penulis pada tahun 2012. Diawali dari pembuatan rumah jaga dan gudang. Dilanjutkan dengan pembangunan konstruksi bingkai keramba, pemasangan pelampung, penjahitan jaring dan pemasangan jaring dalam dan keramba luar.

\section{Teknik penyampaian tujuan dan manfaat kegiatan}

Tujuan disampaikan secara implisit kepada para pengusaha target pembinaan, yaitu melalui demontrasi kegiatan manajemen usaha. Para peserta mula-mula diajak berkenalan dengan cara mengunjungi mereka di keramba mereka masing-masing. Mereka tidak diajak untk datang ke keramba role model, melainkan mereka yang datang sendiri. 


\section{Jumlah karyawan dan sistem penggajian karyawan}

Penghitungan jumlah karyawan yang dibutuhkan disampaikan melalui percontohan langsung antara rasio jumlah karyawan dengan unit keramba yang dimiliki oleh penulis. Demikian pula sistem penggajian karyawan terinformasikan kepada pengusaha binaan secara implplisit saja. Sistem ini disampaikan melalui perbincanganperbincangan dan diskusi-diskusi tentang usaha. Penyampaian ini diperkuat pula dengan pembicaraanpembicaraan sesama karyawan keramba.

\section{Strategi pengaturan siklus penebaran bibit dan pemanenan}

Siklus penebaran bibit dan waktu pemenan adalah suatu yang beriringan. Lama pemeliharaan berkisar antara 90 sampai 115 hari. Strategi yang dimaksud pada tulisan ini adalah jumlah keramba yang akan dipanen per minggu atau per bulan. Sangat patut dihindari panen serentak dalam jumlah banyak. Manajemen penebaran bibit dan timing pemanenan ini didemontrasikan kepada para petani binaan secara langsung. Hal ini terlaksana karena jarak lokasi usaha yang berdekatan. Selain itu para pekerja keramba (anak keramba) pasti saling berkomunikasi.

\section{Strategi pemasaran hasil panen}

Strategi pemasaran hasil panen diinformasikan melalui diskusi-diskusi. Mulai dari pemilihan pedagang perantara, harga hasil panen, sistem pembayaran dan timing pemanenan.

\section{HASIL DAN PEMBAHASAN}

Unit usaha keramba percontohan (role model) sudah selesai dibangun. Unit usaha ini dibangun sejak tahun 2010, dimulai dari 6 unit keramba, usahanya tumbuh dan pada saat ini sudah berjumlah 60 unit keramba pemeliharaan, 1 unit keramba berok, 2 unit speed boat dan 4 unit rumah jaga (Gambar 1). Sebanyak 5 pengusaha dijadikan target binaan utama. Sampel lokasi unit usaha binaan disajikan pada Gambar 2 dan Gambar 3. Para peserta mula-mula diajak berkenalan dengan cara mengunjungi mereka di keramba mereka masing-masing. Mereka tidak diajak untk datang ke keramba role model, melainkan mereka yang datang sendiri. Posisi penulis sebagai pengusaha keramba juga dan relatif sukses serta menjalin hubungan bisnis sebagai sesama pengusaha keramba membuat komunikasi penulis dengan mereka lebih mudah, sehingga pesan-pesan pembinaan itu dapat disampaikan secara efektif walaupun para pengusaha tersebut tidak pernah merasa dibina. Wati dan Primyastanto (2018) dan PPPKP (2018) menyatakan bahwa adanya "rasa seprofesi", rasa senasib sepenanggungan, merasa sama-sama bagian dari sistem usaha, antara pembina dengan yang dibina akan memudahkan penyampaian informasi pembinaan dari satu pihak ke pihak lain.

Cara penyampaian informasi yang digunakan adalah metoda demontrasi. Para pengusaha binaan langsung melihat dan mendengar perihal materi binaan yang disampaikan. Padmowihardjo (2000) dan Ban dan Hawkins, (2001) menyatakan bahwa metoda demontrasi merupakan salah satu metoda yang efektif dalam menyampaikan pesan-pesan pembinaan kepada para komunitas-komunitas yang menjadi target.

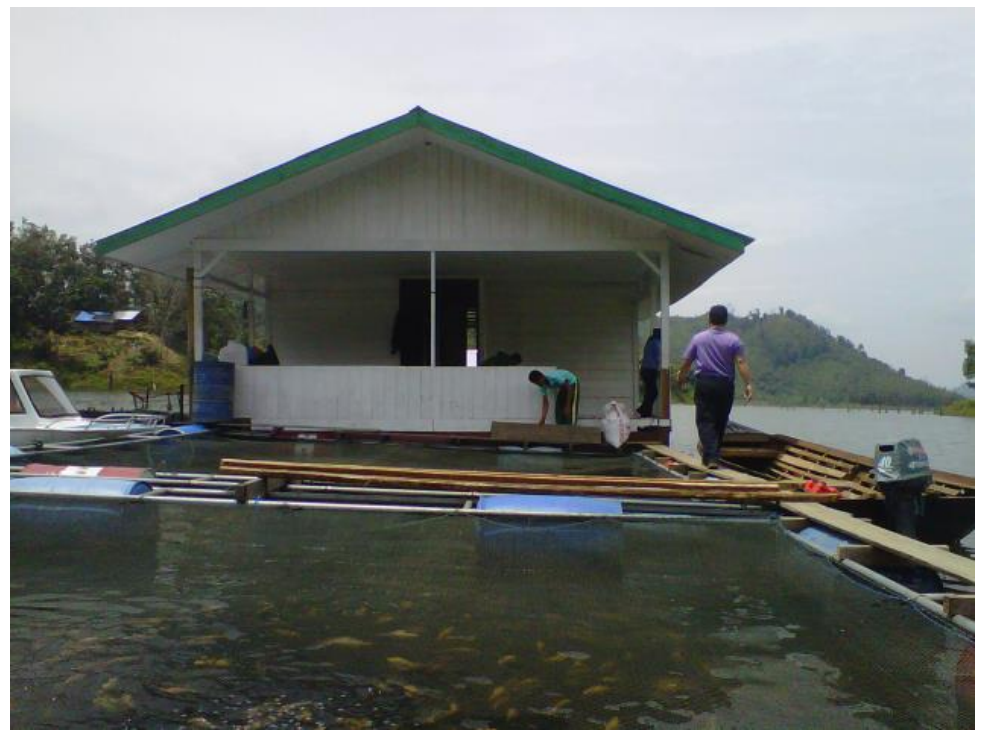

Gambar 1. Unit Usaha Role Model KJA 
Jumlah karyawan dan sistem penggajian (timing dan satuan gaji) merupakan faktor yang sangat menentukan sukses suatu unit usaha (Ban dan Hawkins, (2001). gaji yang proporsional akan memberikan kultur organisasi yang sehat dan menghasilkan kinerja yang lebih baik. Hal ini tentu berlaku pula bagi usaha KJA di Waduk PLTA Koto Panjang. Informasi rasio jumlah karyawan yang dibutuhkan disampaikan melalui percontohan langsung antara rasio jumlah karyawan dengan jumlah unit keramba yang dimiliki penulis. Demikian pula sistem penggajian karyawan disampaikan kepada pengusaha binaan secara implplisit saja. Sistem ini disampaikan melalui perbincangan-perbincangan dan diskusi-diskusi tentang usaha. Penyampaian ini diperkuat pula dengan pembicaraan-pembicaraan sesama karyawan keramba.

Siklus penebaran bibit dan waktu pemanenan adalah suatu yang beriringan. Lama pemeliharaan berkisar antara 90 sampai 115 hari (Gambar 4). Strategi yang dimaksud pada tulisan ini adalah jumlah keramba yang akan dipanen per minggu atau per bulan. Sangat patut dihindari untuk tidak melakukan panen serentak dalam jumlah banyak. Manajemen penebaran bibit dan timing pemanenan ini didemontrasikan kepada para petani binaan secara langsung. Hal ini terlaksana karena jarak lokasi usaha yang berdekatan. Selain itu para pekerja keramba (anak keramba) pasti saling berkomunikasi.
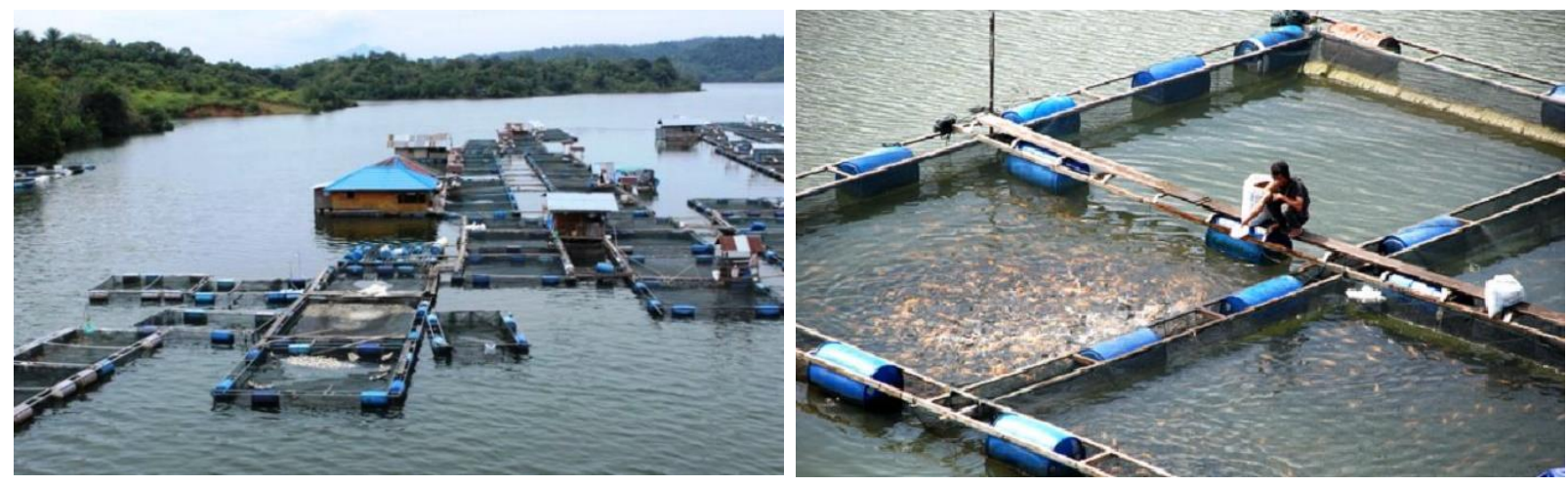

Gambar 2. Unit usaha binaan KJA

Strategi pemasaran hasil panen diinformasikan melalui diskusi-diskusi. Mulai dari pemilihan pedagang perantara, harga hasil panen, sistem pembayaran dan timing pemanenan. Strategi pemasaran amatlah sangat krusial bagi kelanjutan suatu usaha KJA di Waduk PLTA Koto Panjang. Hal ini mengingat usaha KJA ini merupakan usaha padat modal (Nugroho, 2012, Soedijanto, 2004), yaitu memerlukan modal yang banyak dengan proft margin yang kecil. Kesalahan pemilihan pembeli (pedagang perantara), keterlambatan penagihan dan sistem penjualan yang tidak sesuai, akan sangat beresiko tinggi untuk tidak tertagihnya hasil penjualan panen tersebut (Feisal, 2017, Yuddhodan Aditama, 2010).

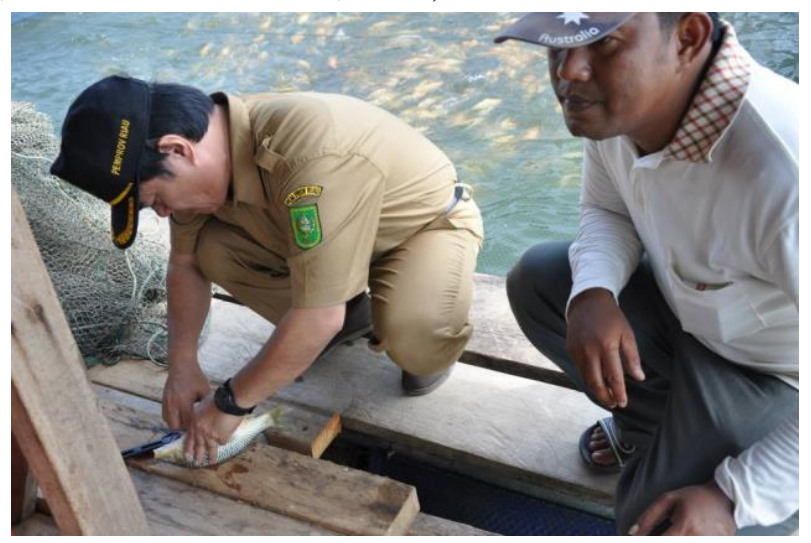

Gambar 4. Komunikasi saat panen KJA

Aspek teknis pelaksanaan kegiatan pengabdian masyarakat ini dievaluasi secara berkala. Hasil evaluasi terhadap kegiatan diperoleh beberapa catatan berikut:

1. Para peserta bianaan tertarik untuk meniru percontohan role model yang dibangun. Hal ini terlihat dari komunikasi yang baik antara penulis, karyawan penulis dengan pengusaha dan karyawan pengusaha KJA binaan. 
2. Hasil pengamatan menunjukan bahwa secara bertahap para pengusaha binaan mulai meniru beberapa aspek yang dicontohkan sesuai dengan kondisi unit usaha mereka masing-masing.

3. Berdasarkan hasil evaluasi yang dilakukan terlihat bahwa mereka mampu bertahan dengan kondisi tekanan usaha, bahkan secara bertahap mulai menemukan titik terang ke arah pengembangan.

\section{KESIMPULAN}

Dari hasil pengabdian kepada masyarakat yang dilaksanakan di Waduk PLTA Koto Panjang, Desa Pulau Gadang, Kecamatan XIII Koto Kampar, Kabupaten Kampar, Provinsi Riau, ditarik kesimpulan sebagai berikut:

1. Para peserta bianaan tertarik untuk meniru percontohan role model yang dibangun.

2. Secara bertahap para pengusaha binaan mulai meniru beberapa aspek yang dicontohkan sesuai dengan kondisi unit usaha mereka masing-masing.

3. Para pengusaha KJA binaan dapat terhindar dari kebangkrutan dan masih bisa bertahan menggeluti usaha tersebut.

\section{SARAN}

Dari hasil pengabdian kepada masyarakat yang dilaksanakan penulis menyarankan kepada para pengusaha binaan unuk terus menjalankan kosep aman berbisnis usaha KJA di Waduk PLTA Koto Panjang. Disarankan kepada pihak pemerintah untuk terus melakukan pemantauan perkembangan sistem usaha KJA ini.

\section{UCAPAN TERIMA KASIH}

Penulis mengucapkan terima kasih kepada Lembaga Penelitian dan Pengabdian Kepada Masyarakat, Universitas Riau yang telah memberi dukungan publikasi kegiatan pengabdian kepada masyarakat ini.

\section{DAFTAR PUSTAKA}

Ban, van den, A.W., \& Hawkins, A.S. 2001. Penyuluhan Pertanian. Kanisius. Yogyakarta.

Dinas Perikanan Kabupaten Kampar. 2016. Laporan Kinerja Instansi Pemerintah Dinas Perikanan Kampar. Pemerintah Kabupaten Kampar. Bangkinang.

Feisal, F. 2017. Analisis Efisiensi Ekonomi Pada Penggunaan Faktor Faktor Produksi Ikan Mas. Universitas Pendidikan Indonesia. Bandung.

Nugroho, E. 2012. Keragaan Produksi Budidaya Ikan Mas di KJA Waduk Ir. H. Djuanda, Jatiluhur. Media Akuakultur, 7.

PPPKP. 2018. Pedoman Kerja Penyuluh Perikanan Tahun 2018. Pusat Pelatihan dan Penyuluhan Kelautan dan Perikanan. Badan Riset Dan SDM Kelautan Dan Perikanan

Padmowihardjo, S. 2000. Metode Penyuluhan Pertanian, Universitas Terbuka, Jakarta.

Soedijanto. 2004. Menata Kembali Penyuluhan Pertanian di Era Agribisnis. Departemen Pertanian, Jakarta.

Wati, L. A., \& M. Primyastanto. 2018. Ekonomi Produksi Perikanan dan Kelautan Modern. UB Press. Malang.

Yuddho, M. W. H. P., \& Aditama, F. 2010. Metode Penyuluhan Kelautan dan Perikanan. Modul Diklata Dasar Jabatan Fungsional Penyuluh Perikanan Tingkat Ahli. Pusat Pelatihan Kelautan dan Perikanan. Kementerian Kelautan dan Perikanan 